\title{
The Rebelling Character on Sister Carrie from Theodore Dreiser
}

\author{
Liu Yan
}

Canvard College, Beijing Technology and Business University, No. 1 Song Zhuang Nan Lu, Tong Zhou Dist, Beijing, China

liuyan_662003@163.com

\section{Keywords: Sister Carrie, American life, Movement of Feminist, Rebelling Character.}

\begin{abstract}
At the end of the nineteenth century comes a generation of Naturalism writers whose ideas and consciousness focus on the workings of the universe and the society's disorders, and they also like to have the harsher insight into the reality, especially the distinctive rebelling traits on Sister Carrie written by Theodore Dreiser. Dreiser fundamentally changes the Femininity by describing Sister Carrie, who used to be a countryside girl easily at the mercy of man, becomes a financially independent "New Woman" by being self-reliance, which forms a contrast to the "True Women" in the genteel tradition. As the heroine of the novel, she has either no confession of her immoral wrongdoing or a tragic death in pain, but the story ends in the enormous success of Carrie, which is a big surprise ending. The author shows us clearly that American traditional moral and social practices misunderstand the real human nature, so are the traditional novels. The book becomes a literary evidence of the rising Feminist Movement of the 19th century. By reviewing the book Sister Carrie and the depiction of independent rebellious characters on Sister Carrie, I would like to reveal and demonstrate the real life of the United States during the period of monopoly capitalism.
\end{abstract}

\section{Introduction}

With the publication of the Sister Carrie in 1900, Dreiser commits his literary force to opening the new ground of American Naturalism, which is new and shocking to reading public reared on genteel romances and adventures. His own experience in Chicago and New York is the perfect realistic materials for the story of a poor country protagonist, Sister Carrie, who comes to the city to seek whatever she can find. One thing she is certain of that she does not wish to remain poor, so she subordinates everything to her rebelling ambitions. Carrie does rise and succeed in the end, but she does so by the means of a male step ladder: one is the Drouet, the traveling salesman Carrie meets in the train to Chicago, another man is Hurstwood who is the bartender and manager of a prominent Chicago tavern. At that time, it is surprising that Dreiser escapes writing a maudlin tale of a fallen girl rescued at the end and the men in this novel are the ones being preyed upon, which consolidate his position and power as one of the American's foremost novelists.

\section{The Reflection of American Life}

\subsection{American Life}

Industrialism, science and the new philosophy of life give rise to the "Modern America", which undergoes the economic, social and cultural transformations after the war, so new ideas about man and man's place in the universe begins to take root in America. Life becomes a struggle for survival. The Darwinian concepts like "the survival of the fittest" and "the human beast" gain popularity and become the moral reference in an amoral world.

Theodore Dreiser knows the hardship of the life of the underclass people. Like other writers, he writes this novel to reveal the reality-the unemployment, poverty and starvation under flourishing prospect of American capitalism in the last of 19th century. The Chicago of the novel is the Chicago Dreiser knows in his youth and is painstakingly accurate in its references to streets, hotels, and 
restaurants, he also depicts the helplessness and insignificance of the man, such as Hurstwood, in the crushing forces of environment and heredity by objectively accumulating the factual details.

\subsection{The movement of Feminist}

"The Feminist movement" (1880-1920) is the first time that pushes the conception of "New Woman" on the history stage. As historian Barbara Welter Describes: "True Women" were expected to be pious, pure, domestic, and submissive[1]. However a competing model for Femininity emerged in the U.S around the 1880s. The "New Women" typically has a career and is economically independent, which is the production of the Industrial Revolution, Sister Carrie is given many tints of individual characters and the character-developing is shown clearly: from a country girl who is under the control to an independent "New Women", which has rewritten the traditional concepts of "Femininity". At the beginning, she puts all her hopes on the men, so she considers the "kindness and geniality" from Drouet and Hurstwood as the protection against the outside dangers. After a long time, Carrie finds the talents for acting accidentally, she does have a career and her ability is shown entirely when her hope for men is shattered completely. She decides to become independent openly and upright so she leaves Hurstwood. The decision shows the self-consciousness of her, which demonstrates the characters of "New Women" vividly.

\section{The Rebelling Character}

\subsection{Dreiser's reversal of malelfemale roles}

The novel Sister Carrie seems to be the platform which Dreiser explores his unconventional views of the genders. Dreiser uses the men around her to get what she wants, and it is those men who are victimized by her. It would seem that Carrie, while outwardly benign, and possibly even deserving of her portrayal as sweet and innocent at the beginning, soon emerges as a ruthless predator in the hide of a helpless woman. From her relationship with Drouet, she manages to gain the experience and social skills to pursue higher aspirations. When he no longer has anything he can offer her, she drops him in favor of Hurstwood. Hurstwood serves as yet another step in her ladder to success, and when he sinks into poverty and self-disgrace after his divorce, she leaves him in favor of striking out her success on herself. This would seem to be what Dreiser really intends by these definite reversals of male-females roles.

\subsection{Rebelling on morality concepts}

Gentility and Altruism are both suicidal behaviors, in a society in which material is the life centre, money is the norm of success and failure, and the traditional morality is challenged and suspected. Dreiser has to reconsider the place of the morality in the human society. Super-morality is created as a kind of rebelling strength. Carrie is not the person who defends the moral purity in the Victorian Times, because her behavior is driven by self-interest. For example, when Drouet seduces her to leave her sister's house, Dreiser implies, because of the glimmering of reason, she is controlled and led by her instinctive needs by the fact that Drouet stands for, at this point, the opulence of Chicago which she imagines and he will supply everything far superior to that provided by the Hansons, and on a level commensurate with her "craving for pleasure". Dreiser's attempt in the passage is to free Carrie form moral responsibility for her action-to suggest that not only Carrie but most men at the stage of evolutionary development are more led than leading. Dreiser believes that "there are three different kinds of moral principles and these exist in a hierarchal order" [2]. But both conventional and evolutionary morals are inadequate to explain the characters in this novel; only the last one-aesthetic morality "... finds a rationale for action in an emotional response to the beauties of life" [2]. So Hurstwood dies being tired of the struggle, while Carrie succeeds in the end with material affluence and the promise of an aesthetic world in her shaking chair. It represents an astonishing breakthrough in the presentation of amoral actions by characters estranged from the social and sexual pretenses of their day. 


\section{Conclusion}

Carrie's "revolt" is quiet but decisive. Finding the conventional domestic sphere for women menial as well as stifling, Carrie decides she will not "live cooped up in small flat" with someone who treats her like a "servant" [3]. She decides for the second time to go to work, and at this point switches roles with the unemployed Hurstwood. What Dreiser calls the "beginning of the new order" [3] occurs when Carrie starts earning the money while Hurstwood begins to do the shopping. Carrie is not simply rebelling against her "husband" but more significantly against the role that women were traditionally supposed to follow. Change in the social position of either gender often creates a predicament for the other. This is certainly the case as the "New Woman" comes on the scene, for she "threatened men in ways her mother never did"[4]. Hurstwood's decline illustrates the conclusion of one historian that "the feminine revolt was creating tension and confusion and challenging the masculine paradigm" [5]. Man can be changed or failed, and this establishment "New women" of Carrie, only being dependent on economy, can make it possible to be equal on mind.

"Sister Carrie" is a mature piece of work of high ideological and artistic power. It shows clearly the break of the "genteelism" and the reflection of American reality. It's reasonable enough to be the key attacking-core in the 20th century of America on the basis of Naturalism, the betrayal of the "New Woman" and the tint of rebelling character, which do not only influence the contemporary life, but also the later generation in the field of literature.

\section{References}

[1] Welter, Barbara, The Cult of True Womanhood: 1820-1860, (American Quarterly 18(2), (1966), p. 156

[2] Donald Pizer, The Novel of Theodore Dreiser, A Critical Study, University of Minnesota Press, Minnesota (1977), p. 58-59

[3] Theodore Dreiser, Sister Carrie, Foreign Language teaching and Research Press (1992), p. 362, 395

[4] Smith-Rosenberg, Carroll. Disorderly Conduct: Visions of Gender in Victorian America, Alfred A. Knopf, New York (1985), p. 245

[5] Dubbert, Joe L, A Man's Place: Masculinity in Transition, Englewood Cliffs, N. J: Prentice-Hall (1979), p. 103-104 